\title{
VALIDITAS KONSTRAK INSTRUMEN ADAPTABILITAS KARIER BIDANG KELISTRIKAN
}

\author{
Muhammad Yafie Nuha ${ }^{1}$, Ketut Ima Ismara ${ }^{2}$, dan Nurhening Yuniarti ${ }^{3}$ \\ ${ }^{1}$ Mahasiswa Program Studi Pendidikan Teknik Elektro, PPS UNY \\ ${ }^{2,3}$ Dosen Jurusan Pendidikan Teknik Elektro, FT UNY \\ E-mail: yafie.nuha@gmail.com
}

\begin{abstract}
This research aims to get a proof of the validity career adapt-ability scale in the field of electrical construction. The samples in this research are electrical engineering education students, amounting to 146 students. The data analysis technique used in this research is second order confirmatory factor analysis (CFA). The compatibility of theoretical models with empirical data is determined with the coefficients of Chi-Square, pvalue, CFI (Comparative Fit Index), and RMSEA (Root Mean Square Error of Approximation). The validity of each item in the career adapt-ability scale is determined with the value of factor loading, $t$ value, and the significance level. Item is considered valid if the factor load is more than 0.3, the t-value is greater than 1.96, and the significance level is less than 5\%. The validity of each factor of career adapt-ability is determined with $C R$ (Construct Reliability) and average variance extracted (AVE). Based on the results of the analysis, it is found that the career adapt-ability instrument in the field of electricity consists of 20 items representing four factors, namely concern, control, curiosity, and confidence are categorized valid.
\end{abstract}

Keywords: Construct Validity, Confirmatory Factor Analysis, and Career Adaptability.

\begin{abstract}
ABSTRAK
Penelitian ini bertujuan untuk memperoleh bukti validitas instrumen pengukur konstrak adaptabilitas karier bidang kelistrikan. Sampel dalam penelitian adalah mahasiswa pendidikan teknik elektro yang berjumlah 146 mahasiswa. Teknik analisis data yang digunakan dalam penelitian ini adalah analisis faktor konfirmatori orde kedua. Kesusuaian model teoritis dengan data empiris ditentukan dengan melihat koefisien Chi-Square, pvalue, CFI (Comparatie Fit Index), dan RMSEA (Root Mean Square Error of Approxiamation). Validititas tiap item dalam konstrak adaptabilitas karier ditentukan dengan melihat nilai muatan faktor, nilai $t$, dan taraf signifikasinsi. Item dianggap valid jika muatan faktor lebih dari 0,3, nilai-t lebih besar daripada 1,96, dan taraf signifikansi kurang dari $5 \%$. Validitas tiap faktor dari adaptabilitas karier ditentukan dengan melihat nilai CR (Construct Reliability) dan rerata varian terekstrak. Berdasarkan hasil analisis diperoleh bahwa instrumen adaptabilitas karier bidang kelistrikan terdiri atas 20 butir yang mewakili empat faktor, yaitu perhatian, kontrol, kengintahuan, dan kepercayaan dapat dinyatakan valid.
\end{abstract}

Kata Kunci: Validitas Konstrak, Analisis Faktor Konfirmatori, dan Adaptabilitas Karier.

\section{PENDAHULUAN}

Laju perubahan teknologi memaksa individu untuk beradaptasi dengan cepat terhadap cara baru dalam berkomunikasi, belajar, bekerja, dan hidup. Fleksibilitas dan adaptabilitas penting untuk belajar, bekerja, dan bermasyarakat pada abad ke-21. Syarat mampu bekerja pada abad ke-21 adalah kemampuan untuk cepat memperoleh dan menerapkan pengetahuan baru. Fleksibilitas dan adaptabilitas dapat dipelajari mahasiswa melalui proyek (pembelajaran ) kompleks yang memiliki tantangan untuk diselesaikan. Seringkali materi yang sudah dipelajari tidak dapat diterapkan secara langsung untuk menyelesaikan proyek sehingga menantang mahasiswa untuk beradaptasi dalam mengembangkan gagasan (Trilling dan Fadel, 2009). 
Adaptabilitas karier merupakan salah satu elemen teori pembangun karier, selain kepribadian vokasi dan pengembangan tugas. Teori pembangun karier menjelaskan mengenai interaksi antara perkembangan individu dan sosial dalam dunia kerja (Savickas, 2005:43). Adaptabilitas karier pertama kali diperkenalkan oleh Super untuk menggantikan konsep kematangan vokasi. Pergantian itu dilakukan karena Adaptabilitias karier lebih tepat untuk menggambarkan interaksi antara individu dengan lingkungan dan kompetensi kerja daripada kematangan vokasi (Super dan Knassel, 1981). Konsep mengenai adaptabilitas karier selanjutnya dikembangkan oleh Mark L. Savickas melalui berbagai penelitiannya.

Adaptabilitas karier didefinisikan sebagai bentuk kesiapan seseorang untuk mengerjakan tugas yang tidak diprediksi, melakukan perencanaan, dan berperan aktif terhadap perubahan cara dan kondisi kerja (Savickas, 1997:254). Definisi Savickas secara tersirat menjelaskan bahwa adaptabilitas karier merupakan suatu kemampuan untuk melakukan perubahan diri tanpa kesulitan saat adanya dinamika karier. Adaptabilitas karier merupakan dimensi dari psikososial yang merujuk pada kesiapan dan sumberdaya individu untuk melaksanakan tugas dalam dunia kerja (Savickas, 2005:51). Tugas itu meliputi pelaksanaan serta pengembangan tugas yang ada, transisi karier, dan masalah psikis. Seseorang yang memiliki adaptabilitas tinggi tidak merasakan banyak hambatan dalam mengejar karier, mempunyai banyak minat, dan kualitas hidup lebih tinggi (Soresi, Nota, \& Ferrari, 2012).

Pendapat lain menyatakan bahwa adaptabilitas karier adalah suatu kecenderungan individu dalam memandang kapasitas dirinya untuk merencanakan, menyesuaikan diri, dan bertanggung jawab dalam bekerja, terutama ketika ada kejadian tak terduga (Rottinghaus, 2004:46). Adaptabilitas karier merupakan segala sumber penyesuaian diri dan strategi yang seseorang gunakan dalam proses pembangunan karier selama berada dalam situasi kritis (Negru-Subtirica dkk., 2015:132). Kedua pendapat tersebut menyiratkan bahwa adaptabilitas karier dapat dinilai melalui respon dan tindakan seseorang dalam situasi kritis yang datang secara tidak terduga.

Adaptabilitas karier dapat ditunjukkan dengan berbagai aktifitas yang berkaitan dengan perencanaan, melaksanakan tugas secara efektif dalam berbagai kondisi dan pencarian tantangan baru. Individu yang memiliki adaptabilitas karier tinggi harus bisa menganggap dirinya lebih berharga dalam lingkungan sosial (Spurk, dkk., 2015:3). Adaptabilitas karier meliputi kompetensi secara umun dan perilaku khusus yang digunakan sebagai upaya ansipasi dan penyesuaian diri terhadap perubahan kondisi lingkungan kerja (van Vianen, 2012:718). Adaptabilitas karier dapat diasah melalui perkuliahan yang berbasis pada proyek dan berbagai kegiatan UKM serta PKM (Program Kreativitas Mahasiswa) yang banyak mengandung aktifitas perencanaan.

Adaptabilitas karier memiliki empat dimensi, yaitu perhatian (perhatian terhadap karier masa depan), kontrol (peningkatan kendali diri sebagai usaha mencapai masa depan yang diinginkan), keingintahuan (eksplorasi berbagai kemungkinan skenario masa depan yang akan dihadapi) dan kepercayaan (penguatan kepercayaan diri untuk mencapai keinginan). Empat dimensi adaptabilitas karier diberi nama sesuai dengan fungsinya dan merupakan dimensi pada tingkat tertinggi. Tiap dimensi tingkat tertinggi mengarah pada teori sikap, kepercayaan, dan kompetensi (teori pengembangan karier $\mathrm{ABC} /$ attitude, belief and competency). Teori pengembangan karier ABC merupakan wujud nyata dari sikap untuk menangani tugas perkembangan, negosiasi transisi, dan penanganan trauma pribadi. Tiap dimensi dihubungkan dengan teori ABC (attitudel sikap, belief / kepercayaan dan competencies / kompetensi) yang menggambarkan level 
menengah dari adaptabilitas karier (Savickas, 2005:52).

Berbeda pendapat dengan Savickas, menurut Super adaptabilitas karier terdiri atas lima kemampuan utama. Pertama, kemampuan untuk belajar dari pengalaman dan antisipasi masa depan (perencanaan). Kedua, kemampuan untuk mengajukan pertanyaan, mengumpulkan informasi melalui interaksi dan komunikasi dengan komunitas (eksplorasi). Ketiga, kemampuan untuk mengumpulkan informasi mengenai dunia kerja (Pengumpulan Informasi). Keempat, kemampuan untuk membuat pilihan berdasar pada pengetahuan cara pembuatan keputusan (pembuatan keputusan). Kelima, kemampuan untuk mengembangkan kesadaran diri, pengetahuan diri dan menentukan pilihan secara realistis sesuai dengan keinginan (Orientasi yang realistis) (Savickas, 2005:359).

Berdasarkan berbagai penelitian terakhir berkaitan dengan adaptabilitas karier, empat dimensi adaptabilitas karier yang dikemukanan Savickas lebih cocok digunakan sebagai rujukan utama (Savickas dan Porfelli, 2012). Empat dimensi ini juga digunakan Savickas sebagai pedoman utama dalam penyusunan instrumen adaptabilitas karier, yang dikenal dengan CAAS (Career Adapt-Ability Scale). Penjelasan mengenai empat dimensi adaptabilitas karier secara ringkas dapat dilihat pada

Tabel 1 .

Tabel 1. Deskripsi Adaptabilitas Karier dari Savickas (2005:53).

\begin{tabular}{|c|c|c|c|c|}
\hline $\begin{array}{c}\text { Career } \\
\text { Question }\end{array}$ & $\begin{array}{c}\text { Do I have a } \\
\text { future? }\end{array}$ & $\begin{array}{c}\text { Who owns } \\
\text { my future? }\end{array}$ & $\begin{array}{c}\text { What do I } \\
\text { want to do } \\
\text { with my } \\
\text { future? }\end{array}$ & $\begin{array}{c}\text { Can I do } \\
\text { it? }\end{array}$ \\
\hline $\begin{array}{c}\text { Career } \\
\text { Problem }\end{array}$ & Indifference & Indecision & Unrealism & Inhibition \\
\hline $\begin{array}{c}\text { Adaptability } \\
\text { Dimension }\end{array}$ & Concern & Control & Curiosity & Confidence \\
\hline $\begin{array}{c}\text { Attitudes } \\
\text { and Beliefs }\end{array}$ & Planful & Decisive & Inquisitive & Efficacious \\
\hline Competence & Planning & $\begin{array}{c}\text { Decision } \\
\text { making }\end{array}$ & Exploring & $\begin{array}{c}\text { Problem } \\
\text { solving }\end{array}$ \\
\hline $\begin{array}{c}\text { Coping } \\
\text { Behaviors }\end{array}$ & $\begin{array}{c}\text { Anvare } \\
\text { Involved }\end{array}$ & $\begin{array}{c}\text { Assertive } \\
\text { Disciplined } \\
\text { Wreparatory }\end{array}$ & $\begin{array}{c}\text { Experimenting } \\
\text { Risk-taking } \\
\text { Inquiring }\end{array}$ & $\begin{array}{c}\text { Persistent } \\
\text { Striving } \\
\text { Industrious }\end{array}$ \\
\hline $\begin{array}{c}\text { Relationship } \\
\text { Perspective }\end{array}$ & Dependent & Independent & Interdependent & Equal \\
\hline $\begin{array}{c}\text { Career } \\
\text { Intervention }\end{array}$ & $\begin{array}{c}\text { Orientation } \\
\text { exercises }\end{array}$ & $\begin{array}{c}\text { Decisional } \\
\text { training }\end{array}$ & $\begin{array}{c}\text { Information- } \\
\text { seeking } \\
\text { activities }\end{array}$ & $\begin{array}{c}\text { Self- } \\
\text { esteem } \\
\text { building }\end{array}$ \\
\hline
\end{tabular}

Perhatian merupakan dimensi pertama dan yang paling utama dalam adaptabilitas karier. Perhatian terhadap karier secara esensial merupakan sebuah orientasi untuk mempersiapkan masa depan (Savickas, 2005:52). Orientasi menuntut seseorang untuk menjadi lebih menyadari dan mengenali masa depan yang ingin dicapai dirinya (Savickas,
1997:256). Menurut teori ABC, kompetensi utama yang berhubungan dengan perhatian adalah perencanaan. Kompetensi yang berkaitan dengan perencanaan dapat dipelajari untuk meningkatkan adaptabilitas karier (Savickas, 1997:256). Perhatian mengenai karier masa depan tidak hanya ditunjukan dengan kepedulian, namun juga dengan keterlibatan langsung pada kegiatan yang 
berguna untuk mempersiapkannya (NegruSubtirica dkk., 2015:132).

Dimensi kedua adaptabilitas karier adalah kontrol. Dimensi kontrol berkaitan dengan pengendalian diri dalam usaha untuk mencapai karier yang direncanakan. Kontrol muncul karena individu merasa dan percaya bahwa dirinya bertanggung jawab terhadap karier masa depan yang akan dicapai (Savickas, 2005:54). Menurut Savickas perilaku yang menunjukan kontrol diri antara lain ketegasan, disiplin, dan kemauan. Ada tiga komponen kontrol, yaitu disiplin diri, otonomi, dan tanggungjawab ketika mengambil keputusan (Negru-Subtirica dkk., 2015:132). Pendapat Negru-Subtirica dkk. sesuai dengan teori ABC yang menyatakan bahwa kompetensi utama dari kontrol adalah pengambilan keputusan. Pengambilan keputusan secara tegas dan bertanggung jawab menjadi modal berharga ketika adanya suatu permasalahan dalam pekerjaan. Pengambilan keputusan hendaknya dilakukan secara rasional (Harren, 1979 dalam Savickas, 2005:361) dan tidak bergantung dengan orang lain.

Adanya kontrol diri mendorong individu memiliki keingintahuan yang ditunjukkan dengan belajar mengenai pengetahuan dan tantangan sesuai karier tujuan (Savickas, 2005:55). Belajar dilakukan melalui eksperimen, bertanya, dan kegiatan lain yang bersifat eksplorasi. Eksplorasi merupakan kompetensi utama dari keingintahuan menurut teori ABC. Eksplorasi dilakukan untuk mencari informasi mengenai karier yang dituju. Informasi tersebut menjadi bekal untuk mengembangkan diri melalui belajar agar memiliki kemampuan sesuai dengan karier yang dituju. Sikap utama yang harus dimiliki ketika belajar adalah keberanian dalam mengambil risiko, baik berupa kesalahan maupun kegagalan. Keingintahuan terhadap karier tujuan merupakan bentuk orientasi kearah eksplorasi mengenai kesesuaian dirinya dengan dunia kerja (Negru-Subtirica dkk., 2015:132).
Dimensi terakhir adaptabilitas karier adalah kepercayaan. Percaya terhadap suatu kemampuan dan tindakan dirinya sebagai langkah antisipasi ketika berhadapan dengan masalah atau penanggulangan rintangan (Negru-Subtirica dkk., 2015:132). Menurut teori karier $\mathrm{ABC}$ kompetensi utama dalam kepercayaan adalah pembangunan sikap harga diri. Kepercayaan terhadap diri dapat direfleksikan melalui perilaku gigih atau tidak mudak menyerah, bekerja keras, dan rajin. Menurut teori pembangun karier kepercayaan merupakan perasaan mengenai efikasi diri terhadap kemampuan yang dimiliki untuk memilih pendidikan dan pekerjaan yang pantas (Savickas, 2005:56). Efikasi diri yaitu keyakinan seseorang pada kemampuan untuk mengatur dan melaksanakan tindakan pada situasi yang memiliki prospek (Bandura, 1995:2).

Sesuai dengan pendapat para ahli, maka dapat disimpulkan adaptabilitas karier adalah suatu bentuk kesiapan seseorang dalam menghadapi perubahan yang terjadi saat menjalani karier. Perubahan meliputi transisi karier, cara bekerja maupun dinamika yang terjadi dalam lingkungan. Elektro sebagai bidang yang selalu berkembang seiring dengan kemajuan teknologi menuntut adanya kemampuan adaptabilitas karier pekerja. Bahaya dan risiko kerja yang ada akan berubah sering pergantian cara kerja. Hal ini menuntut adanya prosedur yang lebih sesuai untuk menangani perubahan bahaya dan risiko kerja agar lebih efektif serta efisien dalam pelaksanaannya.

Adaptabilitas karier seseorang tercermin melalui perhatian, kontrol, pengambilan risiko, dan kepercayaan. Keempatnya berkembang sesuai dengan pengalaman yang dimiliki seseorang dan menunjukkan tingkat adaptabilitas karier. Perhatian adalah bagian terpenting dari adaptabilitas karier. Perhatian merujuk pada kepedulian untuk beradaptasi ketika adanya perubahan. Perhatian ditunjukkan melalui sikap kontrol diri untuk bisa 
menjalankan (mengerjakan) tugas yang ada. Tugas yang ada terkadang menuntut adanya keberanian untuk melakukan inovasi guna menyelesaikannya. Kepercayaan terhadap diri untuk menyelesaikan tugas dan berinovasi diperlukan sebagai upaya menjaga motivasi.

\section{METODE}

Penelitian ini berjenis ex-post facto dengan desain korelasional. Penelitian ini termasuk dalam pendekatan kuantitatif dan menggunakan teknik analisis faktor konfirmatori / Confirmatory factor Analysis (CFA). Data diperoleh melalui pendekatan kuantitatif, berbentuk angka yang diolah secara statistik dan hasilnya dideskripsikan. Teknik analisis faktor konfirmatori bertujuan untuk membuktikan model yang dibangun konstrak sesuai dengan teori yang dikembangkan para ahli dan data lapangan.

Penelitian dilakukan pada mahasiswa Jurusan Pendidikan Teknik Elektro Fakultas Teknik Universitas Negeri Yogyakarta pada tahun akademik 2015/2016. Penelitian dikerjakan bulan Agustus sampai dengan November 2015. Penelitian dilakukan pada semester gasal tahun akademik 2015/2016.

Populasi dalam penelitian ini adalah seluruh mahasiswa Jurusan Pendidikan Teknik Elektro FT UNY. Teknik pengambilan sampel pada penelitian ini menggunakan teknik sampling bertujuan (purposive sampling), yang merupakan bagian dari nonprobability sampling. Jumlah sample yang ikut serta dalam penelitian 146 mahasiswa. Faktor yang berpengaruh pada ukuran sampel adalah penggunaan metode estimasi dan kompleksitas model yang dibangun dalam penelitian. Jumlah sampel yang sesuai untuk metode estimasi taksiran maksimal / Maximum Likelihood Estimation (MLE) dan penggunaan 3 konstrak dalam penelitian yaitu antara $100-150$ (Usman, 2014).

$$
\text { Pengukuran dilakukan dengan }
$$
menggunakan teknik nontes melalui kuesioner.
Instrumen pengukuran adaptabilitas karier diukur dengan instrumen CAAS (Career AdaptAbilities Scale) (Savickas dan Porfeli, 2012) yang telah dikembangkan sesuai kebutuhan. CAAS memiliki empat dimensi (perhatian, kontrol, keingintahuan, dan kepercayaan) yang menunjukan proses. Jawaban yang disajikan dalam instrumen penelitian disusun dengan menggunakan skala likert. Jawaban dalam bentuk deskriptif ditransformasikan menjadi angka untuk mempermudah proses analisis. Lima jawaban disajikan dalam penelitian ini, yaitu sangat setuju/selalu (5), setuju/sering (4), ragu/pernah (3), kurang setuju/jarang (2) dan tidak setuju/tidak pernah (1). Penyekoran item dilakukan sesuai dengan tanda kurung pada tiap respon. Item yang berisi pernyataan negatif diberi skor terbalik. Rancangan kisi-kisi instrumen adaptabilitas karier disajikan dalam tabel 2.

Tabel 2. Deskripsi Adaptabilitas Karier dari Savickas (2005:53).

\begin{tabular}{lll}
\hline Faktor & \multicolumn{2}{l}{ Indikator } \\
\hline Perhatian & $\begin{array}{l}\text { Sadar, Terlibat dan } \\
\text { Persiapan }\end{array}$ & dan \\
\hline Kontrol & $\begin{array}{l}\text { Tegas, Disiplin } \\
\text { Kemauan }\end{array}$ & dan \\
\hline Keingintahuan & $\begin{array}{l}\text { Eksperimen, pengambilan } \\
\text { risiko }\end{array}$ \\
\hline Kepercayaan & $\begin{array}{l}\text { Gigih, Bekerja keras dan } \\
\text { Rajin }\end{array}$ \\
\hline
\end{tabular}

Ada dua asumsi utama yang harus dipenuhi dalam penggunaan analisis faktor konfirmatori, yaitu normalitas multivariat dan multikolinieritas. Deteksi terhadap pencilan (outlier) yang menyebabkan ketidaknormalan data diperlukan sebelum uji normalitas dilakukan. Pencilan multivariat dideteksi melalui perhitungan statistik jarak mahalonobis kuadrat. Jika taraf signifikansi / nilai p dari uji mahalanobis kuadrat kurang dari 0,001 maka responden dianggap sebagai pencilan (Hair, dkk., 2014:135; Usman, 2014:135) dan dihapus. Uji normalitas dan deteksi pencilan dilakukan 
secara bertahap dengan menghapus responden yang terbukti sebagai pencilan satu persatu.

Penelitian ini lebih menekankankan terpenuhinya asumsi normalitas multivariat dibanding univariat. Normalitas univariat akan terpenuhi dengan jika sudah memenuhi kriteria normalitas multivariat, namun tidak berlaku hal sebaliknya (Hair, dkk., 2014:69). Normalitas multivariat sudah mencakup asumsi homoskedastisitas dan linieritas (Usman, 2014:131), sehingga pengujian kedua asumsi tersebut bisa ditiadakan. Normalitas data penelitian digunakan untuk menentukan teknik estimasi yang akan digunakan untuk mengestimasi parameter yang dalam model. Jika asumsi normalitas multivariat terpenuhi, maka digunakan teknik estimasi maximum likelihood (MLE) (Hair, dkk., 2014:575). Metode estimasi General Least Square (GLS) dipakai ketika data tidak memenuhi asumsi normalitas (Ghozali dan Fuad, 2014:34). Uji normalitas multivariat dapat dilakukan dengan menghitung harga kritis koefisien multivariat yang merupakan perbandingan antara koefisien kurtosis multivariat dengan kesalahan baku / standar error (SE). Data suatu konstrak penelitian dianggap memenuhi kriteria normalitas multivariat jika harga kritis koefisien multivariat kurang dari harga kritis z (Usman, 2014:147).

Multikolinieritas antar konstrak dapat dideteksi melalui koefisien korelasi. Multikolieritas terjadi jika suatu konstrak mempunyai koefisien korelasi yang sangat tinggi, sebagai acuan dalam penelitian ini digunakan 0,8 (Usman, 2014:132). Korelasi antar konstrak yang lebih besar daripada 0,8 mengindikasikan adanya multikolinieritas.

Terdapat tiga validitas konvergen yang akan digunakan dalam penelitian ini, yaitu muatan faktor, nilai rerata varians terekstrak (average variance extracted / AVE), dan reliabilitas konstrak (construct reliability / CR) (Hair, dkk., 2014:618). Berdasarkan pendapat hair, dkk. tersebut reliabilitas dan validitas adalah satu kesatuan, reliabilitas merupakan bagian dari validitas konvergen. Kriteria muatan faktor terstandar yang digunakan sebagai batasan kriteria minimum adalah 0,3 (Bordens dan Abbot, 2011;474). Validitas suatu item pengukuran juga ditunjukkan oleh nilai C.R. (critical ratio) dan taraf signifikasi jalur tak standar. Nilai C.R. merupakan nilai dari $t$ hitung pada pengujian hipotesis. Taraf signifikansi yang digunakan adalah 5\%, yang berarti sama dengan nilai $t$ tabel 1,96 . Item akan dihapus jika tidak memenuhi kriteria muatan jalur minimum yang telah ditentukan. Penghapusan item dilakukan satu per satu dari yang paling paling rendah, mengingat perubahan muatan faktor akan terjadi saat salah satu item dihapus. Kriteria minimal nilai rerata varians terekstrak adalah 0,5 dan reliabilitas konstrak 0,6 (Hair, dkk., 2014:619).

Kecocokkan model pengukuran yang dibangun dengan data penelitian dapat diukur dengan dengan indeks kecocokkan / Goodness of Fit (GOF). Kecocokkan secara menyeluruh (overall fit) dapat ditunjukkan melalui penggunaan beberapa kriteria indeks yang ada. Ada tiga indeks kecocokkan yang digunakan dalam penelitian ini mengikuti saran Hair, dkk. yaitu $\chi^{2}$ (khai-kuadrat), CFI (Comparative Fit Index) dan RMSEA (Root Mean Square Error of Approximation) (Hair, dkk., 2014:630). Model pengembangan teori dianggap cocok dengan data penelitian jika Nilai signifikansi dari $\chi^{2}>\alpha(5 \%)$, CFI $>0,9$ dan RMSEA $<0,08$ (Hair, dkk., 2014:578-580). Indeks kecocokkan menyatakan tingkat kesesuaian model yang dibangun secara keseluruhan. Jadi, indeks kecocokkan suatu model tidak dapat digunakan untuk memberi penafsiran pada bagian tertentu. Indeks kecocokkan menunjukan kesesuaian data penelitian dengan model yang dikembangkan sehingga dapat digunakan untuk membuktikan kebenaran suatu teori.

\section{HASIL DAN PEMBAHASAN}

Analisis faktor konfirmatori orde kedua digunakan untuk validasi item terhadap faktor 
dan konstrak adaptabilitas karier. Uji prasyarat analisis dilakukan untuk mengetahui keberadaan pencilan, normalitas, dan multikolinieritas data. Hasil uji prasyarat konstrak adaptabilitas karier selengkapnya dapat dilihat pada lampiran enam.

\section{Uji Prasyarat Analisis}

Berdasarkan hasil hitung jarak mahalanobis kuadrat, ada 11 responden terdeteksi sebagai pencilan. 11 responden yang masuk dalam kategori pencilan dihapus. Nilai C.R. normalitas multivariat 10,048 berada diatas 2,58, berarti bahwa hipotesis awal yang menyatakan data penelitian konstrak adaptabilitas karier berdistribusi normal ditolak. Jadi, data penelitian konstrak adaptabilitas karier berdistribusi tidak normal. Metode GLS digunakan untuk memperoleh nilai parameter yang perlu diestimasi dalam analisis faktor konfirmatori konstrak adaptabilitas karier karena asumsi normalitas tidak terpenuhi.

Uji multikolinieritas digunakan untuk mendeteksi adanya korelasi yang tinggi antar item penelitian konstrak adaptabilitas karier. Matriks korelasi antar item digunakan sebagai sarana uji multikolinieritas. Nilai korelasi anter item tidak ada yang lebih besar daripada 0,9, sehingga dapat diambil kesimpulan tidak ada multikolinieritas antar item yang terjadi pada konstrak adaptabilitas karier.

\section{Hasil Analisis Faktor Konfirmatori}

Diagram jalur hasil analisis faktor konfirmatori orde kedua konstrak adaptabilitas karier dapat ditunjukkan pada Gambar 1. Terdapat korelasi antara kesalahan pengukuran d13 dan d24 sebagai hasil modifikasi dari model adaptabilitas karier. Item A13 membahas tentang pencarian informasi sumber bahaya dengan menjelajahi lingkungan dan item A24 tentang belajar keterampilan baru yang mendukung karier. Pencarian sumber bahaya dengan menjelajahi lingkungan merupakan bentuk belajar hal baru (Savickas, 2005:55).
Pengujian hipotesis kecocokkan model secara keseluruhan dengan data penelitian dilakukan dengan $\chi^{2}$ 171,152 ( $\left.\mathrm{p}=0,355\right)$, CFI 0,920 dan RMSEA 0,018. Ketiga nilai indeks kecocokkan model menunjukkan bahwa model konstrak adaptabilitas karier yang dikembangkan secara teoritis cocok dengan data yang diperoleh di lapangan. Berdasarkan hasil tersebut maka model adaptabilias karier yang dikembangkan dalam penelitian dapat diterima ( $f i t)$.

Diterimanya model pengukuran adaptabilitas karier yang diajukan juga didukung oleh muatan faktor butir, koefisien jalur, nilai $\mathrm{t}$ dan taraf signifikansi pada orde pertama yang selengkapnya disajikan pada tabel 3. Muatan faktor pada pada tiap butir dengan faktor yang diukurnya bervariasi dari yang terkecil 0,431 untuk butir A15 hingga yang terbesar 0,863 untuk butir A23. Semua muatan faktor pada orde pertama sudah lebih besar dari ketentuan 0,3 , sehingga tiap butir pengukur dapat dikatakan dapat mempresentasikan faktor yang diukurnya dengan tepat. Nilai pada muatan faktor tiap butir dapat ditafsikan bahwa jika nilai butir naik atau turun sebesar satu satuan maka nilai dari faktor yang diukurnya juga akan mengalami kenaikan atau penurunan sesuai simpangan bakunya.

Pengujian hipotesis pengaruh tiap butir dalam mengukur faktornya dilakukan dengan melihat nilai $\mathrm{t}$ ataupun taraf signifikansinya. Taraf signifikansi pada tiap butir orde pertama sudah lebih kecil dari 5\% dan nilai t sudah lebih besar dari 1,96. Hal ini berarti bahwa tiap butir memiliki pengaruh yang signifikan dalam mengukur faktornya.

Koefisien determinasi tiap butir terhadap faktor pengukurnya bervariasi dari yang terkecil 18,6\% pada butir A10 hingga yang terbesar $74,4 \%$ pada butir A3. Koefisien determinasi pada tiap butir dapat diberi penjelasan bahwa besarnya persentase yang dapat diukur melalui butir tersebut sesuai dengan koefisien determinasi, sisanya adalah hal lain diluar butir tersebut. 
Nilai koefisien reliabilitas konstrak pada faktor perhatian, kontrol, keingintahuan, dan kepercayaan yang dipaparkan pada Tabel 5 juga sudah diatas 0,6 . Namun, nilai varian terekstrak pada keempat faktor perhatian, kontrol, dan keingintahuan masih dibawah 0,5. Berdasarkan nalai yang didapat pada analisis faktor konfirmatori orde pertama, maka validitas tiap butir dalam mengukur faktor dari adaptabilitas karier tergolong sudah cukup baik.
Muatan faktor dan koefisien jalur konstrak adaptabilitas karier sudah memenuhi kriteria minimal 0,3 , bernilai positif, dan signifikan (nilai $\mathrm{p}<0,050$ ). Koefisien determinasi item tersebar dari yang terkecil $18,6 \%$ (item A15) dan terbesar 74,4\% (item A23).

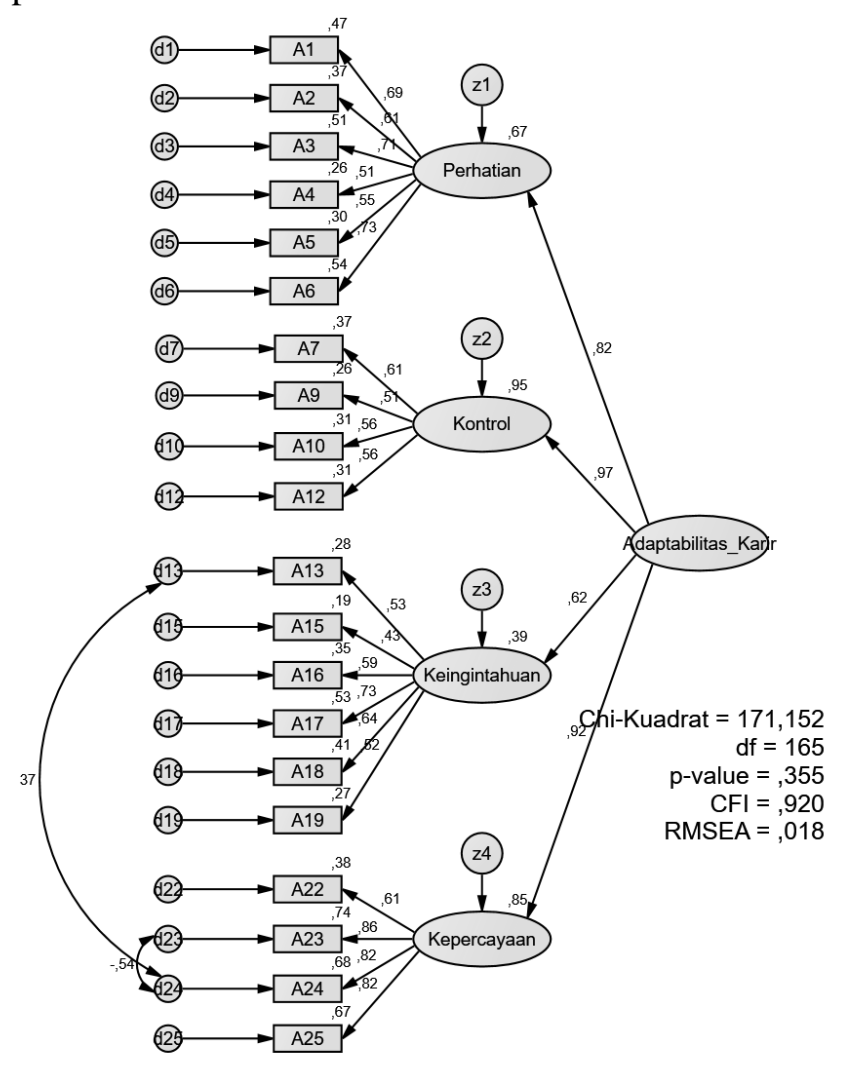

Gambar 1. Diagram Jalur Hasil Analisis Faktor Konfirmatori Adaptabilitas Karier.

Muatan faktor pada pada tiap faktor dengan konstrak adaptabilitas karier bervariasi dari yang terkecil 0,622 untuk faktor keingintahuan hingga yang terbesar 0,972 untuk faktor kontrol. Semua muatan faktor pada orde kedua sudah lebih besar dari ketentuan 0,3 , sehingga tiap faktor pengukur dapat dikatakan dapat mempresentasikan konstrak adaptabilitas karier dengan tepat. Nilai pada muatan faktor dapat ditafsikan bahwa jika nilai faktor naik atau turun sebesar satu satuan maka nilai dari adaptabilitas karier juga akan mengalami kenaikan atau penurunan sesuai simpangan bakunya.

Tabel 3. Koefisien Jalur, Muatan Faktor, Nilai P Adaptabilitas Karier Aanalisis Faktor Orde Pertama.

\begin{tabular}{ccccccc}
\hline $\begin{array}{c}\text { Faktor } / \\
\text { Item }\end{array}$ & $\begin{array}{c}\text { Koefisien } \\
\text { Jalur }\end{array}$ & $\begin{array}{c}\text { Muatan } \\
\text { Faktor }\end{array}$ & Nilai t & $\begin{array}{c}\text { Taraf } \\
\text { signifikansi }\end{array}$ & $\begin{array}{c}\text { Koefisien } \\
\text { Determinasi }\end{array}$ & Keterangan \\
\hline A1 & 1,000 & 0,688 & & &, 674 & Valid \\
\hline
\end{tabular}


Tabel 3. Koefisien Jalur, Muatan Faktor, Nilai P Adaptabilitas Karier Aanalisis Faktor Orde Pertama.

\begin{tabular}{cccccrc}
\hline $\begin{array}{c}\text { Faktor } / \\
\text { Item }\end{array}$ & $\begin{array}{c}\text { Koefisien } \\
\text { Jalur }\end{array}$ & $\begin{array}{c}\text { Muatan } \\
\text { Faktor }\end{array}$ & Nilai t & $\begin{array}{c}\text { Taraf } \\
\text { signifikansi }\end{array}$ & $\begin{array}{c}\text { Koefisien } \\
\text { Determinasi }\end{array}$ & Keterangan \\
\hline A2 &, 837 & 0,610 & 5,397 & $* * *$ &, 675 & Valid \\
\hline A3 & 1,207 & 0,711 & 5,572 & $* * *$ &, 744 & Valid \\
\hline A4 &, 624 & 0,508 & 3,744 & $* * *$ &, 377 & Valid \\
\hline A5 &, 689 & 0,549 & 4,480 & $* * *$ &, 269 & Valid \\
\hline A6 &, 976 & 0,732 & 5,323 & $* * *$ &, 411 & Valid \\
\hline A7 & 1,000 & 0,607 & & &, 532 & Valid \\
\hline A9 &, 966 & 0,510 & 3,575 & $* * *$ &, 350 & Valid \\
\hline A10 &, 870 & 0,560 & 3,688 & $* * *$ &, 186 & Valid \\
\hline A12 &, 869 & 0,558 & 4,180 & $* * *$ &, 281 & Valid \\
\hline A13 & 1,000 & 0,530 & & &, 311 & Valid \\
\hline A15 &, 937 & 0,431 & 3,189 &, 001 &, 313 & Valid \\
\hline A16 & 1,594 & 0,591 & 3,270 &, 001 &, 260 & Valid \\
\hline A17 & 1,937 & 0,730 & 3,881 & $* * *$ &, 369 & Valid \\
\hline A18 & 1,438 & 0,641 & 3,933 & $* * *$ &, 536 & Valid \\
\hline A19 &, 975 & 0,519 & 3,395 & $* * *$ &, 302 & Valid \\
\hline A22 & 1,000 & 0,614 & & &, 258 & Valid \\
\hline A23 & 1,559 & 0,863 & 6,230 & $* * *$ &, 506 & Valid \\
\hline A24 & 1,412 & 0,822 & 5,838 & $* * *$ &, 372 & Valid \\
\hline A25 & 1,299 & 0,821 & 5,984 & $* * *$ &, 473 & Valid \\
\hline
\end{tabular}

Tabel 4. Koefisien Jalur, Muatan Faktor, Nilai P Adaptabilitas Karier Analisis Faktor Orde Kedua.

\begin{tabular}{cccrcrc}
\hline $\begin{array}{c}\text { Faktor } / \\
\text { Item }\end{array}$ & $\begin{array}{c}\text { Koefisien } \\
\text { Jalur }\end{array}$ & $\begin{array}{c}\text { Muatan } \\
\text { Faktor }\end{array}$ & Nilai t & $\begin{array}{c}\text { Taraf } \\
\text { signifikansi }\end{array}$ & $\begin{array}{c}\text { Koefisien } \\
\text { Determinasi }\end{array}$ & Keterangan \\
\hline Perhatian & 1,000 & 0,818 & & &, 846 & \\
\hline Kontrol & 1,056 & 0,972 & 4,701 & $* * *$ &, 387 & Valid \\
\hline Keingintahuan &, 545 & 0,622 & 3,058 &, 002 &, 945 & Valid \\
\hline Kepercayaan &, 886 & 0,920 & 4,338 & $* * *$ &, 670 & Valid \\
\hline
\end{tabular}

Pengujian hipotesis pengaruh tiap faktor terhadap konstrak adaptabilitas karier dilakukan dengan melihat nilai $t$ ataupun taraf signifikansinya. Taraf signifikansi pada tiap faktor orde kedua sudah lebih kecil dari $5 \%$ dan nilai $\mathrm{t}$ sudah lebih besar dari 1,96. Hal ini berarti bahwa tiap faktor memiliki pengaruh yang signifikan dalam mengukur konstrak adaptabilitas karier.

Koefisien determinasi untuk faktor kontrol, kepercayaan, perhatian, dan keingintahuan secara berurutan adalah 94,5\%, $84,6 \%$, 67\%, dan 38,7\%. Hal ini dapat dijelaskan bahwa proporsi varian faktor kontrol yang dapat dijelaskan oleh item pengukurnya sebesar 94,5\%. Begitu juga dengan proporsi varian faktor kepercayaan, perhatian, dan keingintahuan yang dapat dijelaskan oleh item pengukurnya sebesar $84,6 \%, 67 \%$, dan $38,7 \%$.

Nilai koefisien rerata varian terekstrak dan reliabilitas konstrak adaptabilitas karier selengkapnya dapat dilihat pada Tabel 5. Semua nilai reliabilitas konstrak adaptabilitas karier tesudah berada diatas kriteria minimum $(C R>0,6)$. Nilai koefisien rerata varians terekstrak pada orde pertama masih berada dibawah kriteria 0,5 , hanya faktor kepercayaan yang memenuhi kriteria nilai rerata varians 
terekstrak diatas 0,5. Nilai koefisien rerata varians terekstrak untuk orde kedua yang ditunjukkan melalui konstrak adaptabilitas karier sudah berada diatas 0,5. Hal ini menunjukkan bahwa model sudah memiliki reliabilitas dan dapat merepresentasikan konstrak adaptabilitas karier bidang elektro dengan baik.

Tabel 5. Perhitungan Indeks Rerata Varians Terekstrak dan Reliabilitas Konstrak Adaptabilitas Karier.

\begin{tabular}{lll}
\hline \multicolumn{1}{c}{ Konstrak } & $\begin{array}{c}\text { Rerata } \\
\text { Varians } \\
\text { Terekstrak }\end{array}$ & $\begin{array}{c}\text { Reliabilitas } \\
\text { Konstrak }\end{array}$ \\
\hline $\begin{array}{l}\text { Adaptabilitas } \\
\text { karier }\end{array}$ & 0,712 & 0,906 \\
\hline Perhatian & 0,408 & 0,802 \\
\hline Kontrol & 0,313 & 0,645 \\
\hline Keingintahuan & 0,338 & 0,749 \\
\hline Kepercayaan & 0,618 & 0,864 \\
\hline
\end{tabular}

Hasil analisis yang telah dilakukan pada data penelitian menunjukkan bahwa secara keseluruhan instrumen adaptabilitas karier yang telah dikembangkan secara teoritis dan empiris telah terbukti valid. Jumlah item akhir dari hasil analisis sebanyak 20 item. Hasil ini sesuai dengan penelitian sebelumnya yang telah menguji validitas adaptabilitas karier pada 13 negara (Savickas dan Porfeli, 2012).

\section{SIMPULAN}

Instrumen adaptabilitas kerier bidang kelistrikan yang telah disusun melalui kajian teoritis dan uji coba empiris terbukti valid. Adaptabilitas karier bidang kelistrikan dapat terukur melalui empat faktor, yaitu perhatian, kontrol, kengintahuan, dan kepercayaan. Keempat faktor dapat diwakili oleh 20 butir kuesioner. Bukti validitas diperoleh melalui analisis sistem konfirmatori orde kedua.

\section{Saran}

Instrumen yang telah diuji validitasnya ini dapat digunakan untuk mengukur adaptabilitas kerier bidang kelistrikan.
Khususnya untuk mengukur adaptabilitas karier dari peserta didik / siswa / mahasiswa / peserta diklat pada bidang kelistrikan. Hasil penelitian ini dapat dikembangkan lebih lanjut dengan melakukan validasi silang pada sampel yang lebih beragam.

Guna meningkatkan adaptabilitas karier bagi peserta didik pada khususnya maupun pihak lain, maka penyusunan program pembelajaran dapat dilakukan dengan fokus pada aktifitas untuk memperkuat perhatian, kontrol, keingintahuan, dan kepercayaan. Peningkatan adaptabilitas karier melalui memperkuat perhatian, kontrol, keingintahuan, dan kepercayaan juga dapat diterapkan instansi lain, seperti perusahaan maupun lembaga lainnya. Selain itu, faktor perhatian, kontrol, keingintahuan, dan kepercayaan dapat digunakan untuk meningkatkan adaptabilitas karier diri secara individu.

\section{DAFTAR RUJUKAN}

Hair Jr, J. F. et. al. 2014. Multivariate data analysis seventh edition. Essex: Pearson Education Limited 2014.

Negru-Subtirica, O., Pop, E. I., \& Crocetti, E. 2015. Developmental trajectories and reciprocal associations between career adaptability and vocational identity: A three-wave longitudinal study with adolescents. Journal of Vocational Behavior, 88, 131-142. http://doi.org/5xm

Rottinghaus, Patrick Joseph. 2004. "Assessing career optimism and adaptability: toward the construct validation of the Career Futures Inventory". Retrospective Theses and Dissertations. Paper 1120. http://lib.dr.iastate.edu/rtd/1120.

Savickas, M. L. 1997. Career Adaptability: An Integrative Construct for Life-Span, Life-Space Theory. The Career Development Quarterly, 45: 247-259. http://doi.org/fx6bxg

Savickas, M. L. 2005. The theory and practice of career construction. In S. D. Brown, 
\& $\quad$ R.W. Lent (Eds.). Career development and counseling (pp. 4270). Hoboken, New Jersey: John Wiley \& Sons, Inc.

Savickas, M. L., \& Porfeli, E. J. 2012. Career Adapt-Abilities Scale: Construction, reliability, and measurement equivalence across 13 countries. Journal of Vocational Behavior, 80(3), 661-673. http://doi.org/fx73kg

Soresi, S., Nota, L., \& Ferrari, L. 2012. Career Adapt-Abilities Scale-Italian Form: Psychometric properties and relationships to breadth of interests, quality of life, and perceived barriers. Journal of Vocational Behavior, 80(3), 705-711. http://doi.org/625

Spurk, D., Kauffeld, S., Meinecke, A. L., \& Ebner, K. 2015. Why Do Adaptable People Feel Less Insecure? Indirect Effects of Career Adaptability on Job and Career Insecurity via Two Types of Perceived Marketability. Journal of Career Assessment, 1-18. http://doi.org/5xk

Super, D. E., \& Knasel, E. G. 1981. Career development in adulthood: Some theoretical problems and a possible solution. British Journal of Guidance and Counselling, 9(2), 194-201. http://doi.org/d7m5zf

Trilling, B., \& Fadel, C. 2009. 21st century skills: Learning for life in our times. San Fransisco: John Wiley \& Sons, Inc.

Van Vianen, A. E., Klehe, U. C., Koen, J., \& Dries, N. 2012. Career adapt-abilities scale-Netherlands form: Psychometric properties and relationships to ability, personality, and regulatory focus. Journal of Vocational Behavior, 80(3), 716-724. http://doi.org/fxt6rw 